\title{
Survey on Socio-Economic Status of Kathiyawadi Horse Owners and Morphometry of Horses in their Home Tract
}

\author{
P.C. Boradiya ${ }^{1}$, H.H. Savsani ${ }^{1}$, J.A. Chavda ${ }^{1}{ }^{*}$, M.D. Odedra $^{1}$, M.R. Chavda $^{1}$, S.S. Patil ${ }^{1}$, \\ H.B. Naliyapara ${ }^{1}$, B.C. Gohil ${ }^{1}$ and J.M. Chaudhry ${ }^{1}$ \\ College of Veterinary Science \& AH, Junagadh Agricultural University, \\ Junagadh- 362001, India \\ *Corresponding author
}

\section{Keywords}

Education level, Income,

Kathiyawadi horse owners, Rearing and management cost, Socio economic status

Article Info

Accepted:

28 February 2019

Available Online:

10 March 2019

\section{A B S T R A C T}

This study was undertaken to investigate Socio-economic status of Kathiyawadi horse owners in their home tract to find the education level, Strength of horse, rearing cost, income from the horse, land holding and average body weight of horsesof organized and unorganized horse farms in Saurashtra region of Gujarat State. Survey was carried out in Junagadh, Botad, Surendranagar and Bhavnagar districts of Gujarat State, eight talukas of each district was selected and from each selected taluka, ten villages were selected randomly. Five respondents were selected randomly from each village. Thus, random total samples of 400 horse owners were selected for the study. The data was collected through personal interview schedule. The study show that maximum $(74.5 \%)$ horse owners rear horses for pleasure while only 25.5 per cent horse owner rear for traveling, carting and racing and majority $(49.5 \%)$ of the horse owners were having primary level of education while 22.25 per cent had secondary and above level of education, whereas 28.25 per cent were illiterate and majority $(50.5 \%)$ of the horse owners have medium land holding followed by small (45.75\%) and large (3.75 \%) land holding. Majority ( $85 \%)$ of horse's owners possessed small size followed by medium size $(9.5 \%)$ and large size $(5.5 \%)$ herds. the average rearing and management cost of horses of various talukas of different district ranged from Rs. 3620.00 to 7400.00 per month and majority ( $74.5 \%$ ) of the horse owners were not responding to incomes from the horses while 14 per cent horse owner have earn 20000 to 80000 rupees per year and about 11.5 per cent earn above 80000 rupees per year.

\section{Introduction}

India is very prosperous in the wealth of livestock. Some species are directly related with the production and some are indirectly, amongst which horse is important animal belonging to family equidae and its close relatives are ponies, donkeys, mules, zebra etc. (Nehra, 2002). Utilization of horse is increasing in army, paramilitary forces and police department for patrolling, mobility, riot control duties and other activities (Fazili and Kirmani, 2011).There are about 108.9 million equines in the world, comprising of 55.8, 12.8 
and 40.3 million horses, mules and donkeys, respectively (Anon., 2014). The population of horse, mule and donkey, in India has increased by 625, 196 and 319 thousands respectively in 2012 (Livestock Census2012). Gujarat state is very famous for some important horse breeds like Kathiyawadi and Marvadi. Hardly any literature is available on Kathiyawadi horse. Also housing practices and management practices adopted by the horse owners are not available at present. Hence, the study was planned to know the status of horse feeding and management adopted by horse owners in four districts of Gujarat state.

\section{Materials and Methods}

The present study was carried out in organized and unorganized horse farms of Junagadh, Botad, Surendranagar and Bhavnagar districts of Gujarat state. Gujarat division consists of 33 districts. Survey was conducted in four districts of the Gujarat having appreciable equine population viz Junagadh, Bhavnagar Surendranagar and Botad district. Two talukas from each selected districts was selected randomly for the study purpose. Thus, a total 8 talukas were chosen randomly, from each selected taluka 10 villages were selected randomly. Thus the study was confined to total 80 chosen villages from Junagadh, Botad, Surendranagar and Bhavnagar districts. Thus Random total samples of 400 Kathiyawadi horse owners were selected for the study. Personal interview technique was used as a tool through which first-hand information was collected. The data was collected by personal interview from Kathiyawadi horse owners.Body weight was calculated using body measurements (Gina, 2010).

\section{Statistical analysis of the data}

Data were collected on Performa recording sheets, were processed and analyzed as per
Snedecor and Cochran (1994). Basic statistical tools like frequency distribution, percentage, mean, range, standard error, $\mathrm{Z}$ test, $t$ test and ratio etc., were used to draw the inferences.

\section{Results and Discussion}

Personal, social and economic characteristics

Age is an important factor, which influences the behavior pattern of individual.Data indicate that maximum (59\%) horse owners belonged to middle age category followed by young (24\%) and old (17\%). Further, the middle age group has better experience and interest, so they were always ready to adopt new innovations (Table-1). The findings of present study are in agreement with the findings of Hassan et al., (2016b). The level of education of the respondents was studied and presented in Table-2.Majority (49.5\%) of the horse owners were having primary level of education while 22.25 per cent had secondary and above level of education, whereas 28.25 per cent were illiterate. The findings of present study are agreement with the findings of Hassan et al., (2016b).The information regarding land holding capacity of the horse owners were collected and presented in Table-3.

Majority (50.5\%) of the horse owners have medium land holding followed by small $(45.75 \%)$ and large $(3.75 \%)$ land holding. The findings of present study are parallel and agreement with the findings of Singh and Dubey (1978) and Yaspal et al., (2011).The term animal holding indicates the number of horses kept by horse owners. Majority (Table4) $(85 \%)$ of horse's owner's possessed small size followed by medium size $(9.5 \%)$ and large size $(5.5 \%)$ herds. The findings of present study were related with the findings of Ganai et al., (2004). 


\section{Rearing and Management cost}

Data presented in Table-6 shows that the average rearing and management cost of horses of various talukas of different district ranged from Rs. 3620.00 to 7400.00 per month. Rearing and management cost for horses of Ghogha taluka was maximum with a range of Rs 3000.00-12000.00 per month, whereas, Gadhada taluka was minimum with average of Rs 1000.00-9000.00 per month. The finding of present study is in accordance with the findings reported by Yashpal et al., (2012).

\section{Income from horses}

Majority $(74.5 \%)$ of the horse owners were not responding to incomes from the horses while 14 per cent horse owner have earn 20000 to 80000 rupees per year and about 11.5 per cent earn above 80000 rupees per year (Table-7).The finding of present study are contraindicate with the values reported by Yashpal et al., (2013).

\section{Socio-economic status of equine owners}

The average values of land holdings were recorded as $26.38 \pm 2.42, \quad 41.5 \pm 4.90$, $28.98 \pm 3.13$ and $26.54 \pm 1.88$ vigha/family (1 vigha $=0.16 \mathrm{ha})$ in Junagadh, Botad, Surendranagar and Bhavnagar districts, respectively with an overall average of $30.85 \pm 3.59$ vigha/family (Table-8). Comparable findings were also reported by Singh et al., (2002) and Hassan et al., (2016f).Statistical analysis of the data (Table-
9) revealed significant $(\mathrm{P}<0.05)$ difference in average land holdings of horse owners in the four respective study areas of the districts. Higher land holding per family was observed in Botad district followed by Surendranagar, Bhavnagar and Junagadh. The land holding in Botad district was significantly $(\mathrm{P}<0.05)$ higher than Bhavnagar and Surendranagar districts.

The average rearing cost of horses was recorded as Rs. $5590 \pm 344.02,3940 \pm 360.70$, $6125 \pm 375.93$ and $5575 \pm 373.08$ month/horse in Junagadh, Botad, Surendranagar and Bhavnagar district, respectively with an overall average of Rs. $5307.5 \pm 500.06 \mathrm{month} /$ horse in the district. Looking (Table-10) to the rearing cost (Rupees) of horse owners of Botad (3940) district was found significantly $(\mathrm{p}<0.05)$ higher as compare to Surendranagar (6125) and Bhavnagar (5575) district. While, district like Junagadh (5590) was having significantly $(\mathrm{p}<0.05)$ higher rearing cost as compared to Botad (3940) district. The average income from horses was recorded as Rs. 66526.31 $\pm 6127.00, \quad 49750.00 \pm 7544.51$, $55333.33 \pm 6005.28$ and $94090.90 \pm 12210.43$ per year/horse in Junagadh, Botad, Surendranagar and Bhavnagar districts, respectively with an overall average of Rs. $66425.14 \pm 9859.40$ per year/horse for all districts. Looking to the income from the horses of different district, income from the Bhavnagar (94090.91) district was significantly $(\mathrm{p}<0.05)$ higher as compared to Botad (49750) and Surendranagar (55333.33) district(Table-11).

Table.1 Distribution of respondents according to their age

\begin{tabular}{|c|l|c|c|}
\hline Sr. No. & Category & Frequency & Per cent \\
\hline $\mathbf{1}$ & Young age (up to 35 years) & 96 & 24 \\
\hline $\mathbf{2}$ & Middle age (36 to 50 years) & 236 & 59 \\
\hline $\mathbf{3}$ & Old (above 50 years) & 68 & 17 \\
\hline & Total & $\mathbf{4 0 0}$ & $\mathbf{1 0 0}$ \\
\hline
\end{tabular}


Table.2 Distribution of respondent according to their education

\begin{tabular}{|c|l|c|c|}
\hline Sr. No. & Category & Frequency & Per cent \\
\hline $\mathbf{1}$ & Illiterate & 113 & 28.25 \\
\hline $\mathbf{2}$ & Primary education & 198 & 49.50 \\
\hline $\mathbf{3}$ & Secondary education and above & 89 & 22.25 \\
\hline & Total & $\mathbf{4 0 0}$ & $\mathbf{1 0 0}$ \\
\hline
\end{tabular}

Table.3 Distribution of respondents according to their land holdings

\begin{tabular}{|c|l|c|c|}
\hline Sr. No. & Category & Frequency & Per cent \\
\hline $\mathbf{1}$ & Small (0 to 30 vigha) & 183 & 45.75 \\
\hline $\mathbf{2}$ & Medium (31 to 80 vigha) & 200 & 50.50 \\
\hline $\mathbf{3}$ & Large (Above 81 vigha) & 15 & 3.75 \\
\hline & Total & $\mathbf{4 0 0}$ & $\mathbf{1 0 0}$ \\
\hline
\end{tabular}

Table.4 Distribution of respondents according to their animal holding

\begin{tabular}{|c|l|c|c|}
\hline Sr. No. & Category & Frequency & Per cent \\
\hline $\mathbf{1}$ & Small size (1 to 2 horses) & 340 & 85.00 \\
\hline $\mathbf{2}$ & Middle size (3-4 horses) & 38 & 9.50 \\
\hline $\mathbf{3}$ & Large size (more than 4 horses) & 22 & 5.50 \\
\hline & Total & $\mathbf{4 0 0}$ & $\mathbf{1 0 0}$ \\
\hline
\end{tabular}


Table.5 Average body weight of horses in different talukas $(\mathrm{kg})$

\begin{tabular}{|c|c|c|c|}
\hline Sr.No. & District & Taluka & Average weight (kg) \\
\hline \multirow[t]{2}{*}{1} & \multirow[t]{2}{*}{ Junagadh } & Visavadar & $358.14 \pm 7.13(235.82-478.21)$ \\
\hline & & Bhesan & $403.21 \pm 7.17(319.05-478.41)$ \\
\hline \multirow[t]{2}{*}{2} & \multirow[t]{2}{*}{ Botad } & Botad & $409.84 \pm 7.94(263.6-505.92)$ \\
\hline & & Gadhada & $371.09 \pm 11.17(235.58-498.09)$ \\
\hline \multirow[t]{2}{*}{3} & \multirow[t]{2}{*}{ Surendranagar } & Chotila & $318.05 \pm 8.47(245.7-375.45)$ \\
\hline & & Limadi & $361.68 \pm 9.63(259.02-477.73)$ \\
\hline \multirow[t]{3}{*}{4} & \multirow[t]{2}{*}{ Bhavnagar } & Palitana & $370.01 \pm 10.72(259.02-529.11)$ \\
\hline & & Ghogha & $439.08 \pm 8.07(291.95-498.8)$ \\
\hline & \multicolumn{2}{|c|}{ Total average } & $378.89 \pm 13.18$ \\
\hline
\end{tabular}

Values in parenthesis indicate the range of body weight 
Table.6 Average rearing and management cost (Rs/month/horse)

\begin{tabular}{|c|c|c|c|}
\hline Sr. No. & District & Taluka & Average Rs \\
\hline \multirow[t]{2}{*}{1} & \multirow[t]{2}{*}{ Junagadh } & Visavadar & $\begin{array}{c}3860.00 \pm 430.24 \\
(1000-15000)\end{array}$ \\
\hline & & Bhesan & $\begin{array}{c}7320.00 \pm 413.49 \\
(3000-12000)\end{array}$ \\
\hline \multirow[t]{2}{*}{2} & \multirow[t]{2}{*}{ Botad } & Botad & $\begin{array}{c}4260.00 \pm 571.83 \\
(1000-15000)\end{array}$ \\
\hline & & Gadhada & $\begin{array}{c}3620.00 \pm 409.97 \\
(1000-9000)\end{array}$ \\
\hline \multirow[t]{2}{*}{3} & \multirow[t]{2}{*}{ Surendranagar } & Chotila & $\begin{array}{c}5650.00 \pm 472.78 \\
(1000-15000)\end{array}$ \\
\hline & & Limadi & $\begin{array}{c}6600.00 \pm 590.97 \\
(1000-15000)\end{array}$ \\
\hline \multirow[t]{2}{*}{4} & \multirow[t]{2}{*}{ Bhavnagar } & Palitana & $\begin{array}{c}3750.00 \pm 496.98 \\
(1000-18000)\end{array}$ \\
\hline & & Ghogha & $\begin{array}{c}7400.00 \pm 430.95 \\
(3000-12000)\end{array}$ \\
\hline
\end{tabular}

Values in parenthesis indicate the range of rupees

Table.7 Distribution of respondent according to their income from horses

\begin{tabular}{|c|l|c|c|}
\hline Sr. No. & Income (Rs/Year) & Frequency & Per cent \\
\hline $\mathbf{1}$ & 20000 to 80000 & 56 & 14.00 \\
\hline $\mathbf{2}$ & 80000 and Above & 46 & 11.50 \\
\hline $\mathbf{3}$ & No income (pleasure) & 298 & 74.50 \\
\hline & Total & $\mathbf{4 0 0}$ & $\mathbf{1 0 0}$ \\
\hline
\end{tabular}


Table.8 Socioeconomic status of horse owners in study areas (Overall mean \pm SE)

\begin{tabular}{|c|c|c|c|}
\hline District & $\begin{array}{c}\text { Landholding } \\
\text { Vigha/family }\end{array}$ & $\begin{array}{c}\text { Rearing cost } \\
\text { Rs/Monthly/horse }\end{array}$ & $\begin{array}{c}\text { Income } \\
\text { Rs/Yearly/horse }\end{array}$ \\
\hline Junagadh & $26.38 \pm 2.42$ & $5590.00 \pm 344.02$ & $66526.31 \pm 6127.00$ \\
\hline Botad & $41.50 \pm 4.90$ & $3940.00 \pm 360.70$ & $49750.00 \pm 7544.51$ \\
\hline Surendranagar & $28.98 \pm 3.13$ & $6125.00 \pm 375.93$ & $55333.33 \pm 6005.28$ \\
\hline Bhavnagar & $26.54 \pm 1.88$ & $5575.00 \pm 373.08$ & $94090.90 \pm 12210.43$ \\
\hline Overall mean & $\mathbf{3 0 . 8 5} \pm \mathbf{3 . 5 9}$ & $\mathbf{5 3 0 7 . 5 0} \pm \mathbf{5 0 0 . 0 6}$ & $\mathbf{6 6 4 2 5 . 1 4 \pm 9 8 5 9 . 4 0}$ \\
\hline
\end{tabular}

Table.9 Two sample Z test (Unequal variance) for landholding pattern of different districts

\begin{tabular}{|c|c|c|c|}
\hline Sr. No. & \multicolumn{2}{|c|}{ Districts } & Significance \\
\hline 1 & Junagadh & Botad & \\
\hline Mean & 26.39 & 41.5 & \\
\hline Z Value & -2.76 & & NS \\
\hline 2 & Junagadh & Surendranagar & \\
\hline Mean & 26.39 & 28.94 & \\
\hline Z Value & -0.64 & & NS \\
\hline 3 & Junagadh & Bhavnagar & \\
\hline Mean & 26.39 & 26.54 & \\
\hline Z Value & -0.05 & & NS \\
\hline 4 & Botad & Surendranagar & \\
\hline Mean & 41.5 & 28.94 & \\
\hline Z Value & 2.16 & & $0.05^{*}$ \\
\hline 5 & Botad & Bhavnagar & \\
\hline Mean & 41.5 & 26.54 & \\
\hline Z Value & 2.85 & & $0.05^{*}$ \\
\hline 6 & Surendranagar & Bhavnagar & \\
\hline Mean & 28.94 & 26.54 & \\
\hline Z Value & 0.65 & & NS \\
\hline
\end{tabular}

Note:-* -Significance at $5 \%$ level $(\mathrm{p}<0.05)$, NS- Non significant 
Table.10 Two sample Z test (Unequal variance) for rearing cost of horses from different districts

\begin{tabular}{|c|c|c|c|}
\hline Sr. No. & \multicolumn{2}{|c|}{ Districts } & \multirow[t]{2}{*}{ Significance } \\
\hline 1 & Junagadh & Botad & \\
\hline Mean & 5590 & 3940 & \\
\hline Z Value & 3.60 & & $0.05^{*}$ \\
\hline 2 & Junagadh & Surendranagar & \\
\hline Mean & 5590 & 6125 & \\
\hline Z Value & -0.92 & & NS \\
\hline 3 & Junagadh & Bhavnagar & \\
\hline Mean & 5590 & 5575 & \\
\hline Z Value & 0.00 & & NS \\
\hline 4 & Botad & Surendranagar & \\
\hline Mean & 3940 & 6125 & \\
\hline Z Value & -4.35 & & $0.05^{*}$ \\
\hline 5 & Botad & Bhavnagar & \\
\hline Mean & 3940 & 5575 & \\
\hline Z Value & -3.45 & & $0.05^{*}$ \\
\hline 6 & Surendranagar & Bhavnagar & \\
\hline Mean & 6125 & 5575 & \\
\hline Z Value & 0.90 & & NS \\
\hline
\end{tabular}

Note:-* -Significance at $5 \%$ level $(\mathrm{p}<0.05)$, NS- Non significant 
Table.11 Two sample T test (Unequal variance) for income from horses of different districts

\begin{tabular}{|c|c|c|c|}
\hline Sr. No. & \multicolumn{2}{|c|}{ Districts } & Significance \\
\hline 1 & Junagadh & Botad & \\
\hline Mean & 66526.32 & 49750 & \\
\hline T Value & 1.73 & & NS \\
\hline 2 & Junagadh & Surendranagar & \\
\hline Mean & 66526.32 & 55333.33 & \\
\hline T Value & 1.30 & & NS \\
\hline 3 & Junagadh & Bhavnagar & \\
\hline Mean & 66526.32 & 94090.91 & \\
\hline T Value & -2.02 & & NS \\
\hline 4 & Botad & Surendranagar & \\
\hline Mean & 49750 & 55333.33 & \\
\hline T Value & -0.58 & & NS \\
\hline 5 & Botad & Bhavnagar & \\
\hline Mean & 49750 & 94090.91 & \\
\hline T Value & -3.09 & & $0.05^{*}$ \\
\hline 6 & Surendranagar & Bhavnagar & \\
\hline Mean & 55333.33 & 94090.91 & \\
\hline T Value & -2.85 & & $0.05^{*}$ \\
\hline
\end{tabular}

Note:-* -Significance at $5 \%$ level $(\mathrm{p}<0.05)$, NS- Non significant 


\section{Average body weight}

Data presented in Table-5 show that the average body weight of horses of various talukas of various district was ranged from 358.14 to $439.08 \mathrm{~kg}$. The average weight of horses in Ghoghataluka was maximum with a range of $291.95-498.8 \mathrm{~kg}$. Whereas, those of average weight of horses in Chotilataluka was minimum with a range of $245.7-375.45 \mathrm{~kg}$. Overall average body weights of horses were found to be $378.89 \mathrm{~kg}$ and it is near to the standard average body weight of adult horses as suggested by NRC (2007).The findings of present study are in line with the findings of Gallagher et al., (1992), Burk et al., (2008), Rao et al., (2010) and Hassan et al., (2016b).

In conclusion, based on study, it was observed that many of the horse owners (49.5 per cent) were having primary level of education and almost all the horses owner opined that the pleasure was the only purpose of keeping the horses.

Overall average body weights of horses were found to be $378.89 \mathrm{~kg}$ and it is near to the standard average body weight of adult horses as suggested by NRC (2007).

\section{Acknowledgement}

The authors thank Animal nutrition department, College of Veterinary Science and A.H. JAU, Junagadh for providing space and all facilities to conduct this experiment. We also thank Principal and Dean, Veterinary College, JAU, Junagadh for providing necessary support for conducting this experiment.

\section{References}

Burk, A., O. and Williams, C. A. (2008). Feeding management practices and supplement use in top level event horses. Comp. Ex. Physiol. 5(3):85-93.
Fazili, M. R. and Kirmani, M. A. (2011). Equine: The Ignored Working Animal of Gujarat: Status, Constraints, Research Areas and Ways for Improvement. Asian. J. Anim. Sci., 5(4): 91-101.

Gallagher, K., Leech, J and Stowe, H. (1992). Protein, energy and dry matter consumption by racing thoroughbreds: A field survey. J. Eq. Vet Sci., 12(1): 43-48.

Ganai, A. M., Matto, F. A., Singh, P. K. and Parray, B.A. (2004). A survey of feeding practices in Kashmir valley. Indian J. Anim.Nutr., 21(2): 69-72.

Gina, T. (2010). How to weigh your horse without a scale. The Feed Room. Retrieved from: www.horsefeedblog.com

Hassan, S., Ganai, A. M., Afzal, Y., Beigh, J., Farooq, G., Shiekh, G. and Ahmad, H. A. (2016b). A study on socio-economic status of equine owner, shelter pattern and morphometry of horses in district Barmulla of Kashmir Valley. Paper presented in $10^{\text {th }}$ Biennial Animal Nutrition Association Conference on Newer perspectives in animal nutrition research for augmenting animal productivity, held at Tirupati during Nov. 2016, pp 4.

Hassan, S., Ganai, A. M., Afzal, Y., Beigh, J., Farooq, G., Shiekh, G. and Ahmad, H. A. (2016f). A study on socio-economic status of equine owner, shelter pattern for horses in Budgam district of Kashmir Valley. Paper presented in XVI Biennial Conference on Innovative approaches for animal feeding and nutritional research, held at ICARNDRI Karnal during 6-8 feb, 2016, pp 277.

Livestock Census (2012). $19^{\text {th }}$ All India Livest ock census. http://dahd.nic.incensus.htm 1.

Nehra, R. (2002). Dietary evaluation of some 
common feed stuffs of arid zone in horses. M.V.Sc. Thesis submitted to Rajasthan Agricultural University, Bikaner, Rajasthan.

NRC (2007). Nutrient Requirements of Horses. 6th Ed. National Academy Press, Washington- DC., USA

Rao, R. K., Agrawal, T. T., Ravikumar, R. K. and Gupta, S.R. (2010). Working equine feeding practices in Uttar Pradesh, India: with specific reference to horse and mule. The $6^{\text {th }}$ International Colloquim on Working Equids: learning from others. Proceedings of an international Colloquim, New Delhi, India, pp: 279283 record no. 20113392883.

Singh, D., Yadav, A.S. and Yadav. K. R. (2002).Effect of socio-economic variables in adoption of reproduction management practices in rural Haryana.Indian J. Anim.Nutr.19: 153155.

Singh, S. and Dubey, V. K. (1978). Adoption of scientific feeding practices of cattle owners of the ICDP, Karnal. Indian J. Ext. Edu.14(1-2): 15-20.

Snedecor, G. and Cochran, W. (1994). Statistical Methods.8th edn.Oxford and IBH. New Delhi.

Yashpal, Legha, R. A., Dedar, R. K. and Bala, P. A. (2013) Socio-economic status of horse owners vis-a-vis horse feeding and management in Rajasthan. Vet. World.,6(8): 470-475.

Yashpal, Legha, R. A., Thakur, Y. P., Gupta, A. K. and Singh, R. K. (2011). Socioeconomic status of spiti horse owners vis-a-vis horse management in native tract.Vet. Practitioner, 12(1):73-76.

Yashpal., Legha, R. A., Niranjan, L., Bhardwaj, A., Chauhan, M., Kumar, S., Sharma, R. C. and Gupta, A. K. (2012).Management and phenotypic characterization of donkeys of Rajasthan.Indian J. Anim. Sci.,83 (8): 793-797.

\section{How to cite this article:}

Boradiya, P.C., H.H. Savsani, J.A. Chavda, M.D. Odedra, M.R. Chavda, S.S. Patil, H.B. Naliyapara, B.C. Gohil and Chaudhry, J.M. 2019. Survey on Socio-Economic Status of Kathiyawadi Horse Owners and Morphometry of Horses in their Home Tract. Int.J.Curr.Microbiol.App.Sci. 8(03): 2545-2555. doi: https://doi.org/10.20546/ijcmas.2019.803.302 